\title{
Morphological and phytochemical characterization of Lavandula dentata L. cultivated in Paraíba do Sul, Rio de Janeiro, Brazil
}

\author{
Ana Rosa de Figueiredo®, Leirson Rodrigues da Silva`®, Silvia Michelle Bezerra Camargo ${ }^{a} \bullet$, \\ Lilia Aparecida Salgado de Moraisbo \\ a Programa de Pós graduação em Ciências Tecnologia e Inovação Agropecuária, Universidade Federal Rural do Rio de Janeiro, \\ Seropédica, 23897-000, Rio de Janeiro, Brasil. *ana.agroambiente@gmail.com \\ b Empresa Brasileira de Pesquisa Agropecuária Agrobiologia, Seropédica, 23891-000, Rio de Janeiro, Brasil.
}

Received: October 11, 2020 / Accepted: December 9, 2020 / Published online: January 27, 2021

\begin{abstract}
Lavandula dentata L., popularly known as lavender, is considered to be a medicinal plant that has great economic potential. The aims of the present study were to characterize the morphology of L. dentata grown in Paraíba do Sul, Rio de Janeiro, Brazil and determine the content and chemical composition of its essential oil. Morphology of the plant was determined using the optical microscope, digital calliper and measuring tape. The fresh plant material characteristics consisting of the branches, leaves, and inflorescence were described. The essential oil was obtained by hydrodistillation and analyses chemical characteristics were performed by gas chromatography (GC) and gas chromatography coupled to mass spectrometry (GC/MS). Our study shows a large number of non-glandular trichomes were identified, as well as two types of glandular trichomes, including capitate and peltate glandular trichomes. This work achieved high essential oil content which were related to vegetable biomass. The major constituents found in the essential oil from $L$. dentata were the monoterpenes: eucalyptol - 1.8 cineol (39.43\%), camphor $(20.11 \%)$, and fenchone $(18.40 \%)$. Thus, it was possible to characterize the morphology and chemical composition of L. dentata.
\end{abstract}

Keywords: Lamiaceae, lavender, terpene, morphology, trichome.

\section{Caracterização morfológica e fitoquímica de Lavandula dentata L. cultivada na Paraíba do Sul, Rio de Janeiro, Brasil}

\section{Resumo}

A Lavandula dentata L., conhecida popularmente como lavanda, é considerada uma planta medicinal com grande potencial econômico. Os objetivos do presente estudo foram caracterizar a morfologia de L. dentata cultivada na Paraíba do Sul, Rio de Janeiro, Brasil e determinar o teor e a composição química de seu óleo essencial. A morfologia da planta foi determinadas em microscópio óptico, paquímetro digital e fita métrica. As características do material vegetal fresco consistindo de ramos, folhas e inflorescência foram descritas. O óleo essencial foi obtido por hidrodestilação e as análises das características químicas foram realizadas por cromatografia gasosa (CG) e cromatografia gasosa acoplada a espectrômetro de massas (CG / EM). Nosso estudo mostra que um grande número de tricomas não glandulares foi identificado, assim como dois tipos de tricomas glandulares, incluindo tricomas glandulares capitados e peltados. Este trabalho alcançou um alto teor de óleo essencial relacionados à biomassa vegetal. Os principais constituintes encontrados no óleo essencial de L. dentata foram os monoterpenos: eucaliptol 1,8 cineol $(39,43 \%)$, cânfora $(20,11 \%)$ e fenchona $(18,40 \%)$. Assim, foi possível caracterizar a morfologia e composição química de L. dentata.

Palavras-chaves: Lamiaceae, lavanda, morfologia, terpeno, tricoma.

\section{Introduction}

Lavandula dentata L. (lavender), belongs to the Lamiaceae family and is native to eastern and southern Spain. However, it is well adapted to tropical climates and can be grown at lower latitudes. Most lavender species exclusively grow in Mediterranean climates because they prefer sunny. However, a number of lavender species with distinct characteristics are widely distributed globally (Biasi \& Deschamps, 2009).

In Brazil, lavender cultivation, despite being insipient, has attracted the attention of producers because it can potentially be used in herbal medicines, aromatherapy, cosmetics, perfumery, and cooking. Furthermore, there is a tourist demand for the essential oil and ornamental lavender species. However, there is a lack of basic knowledge about 
growing the species in different regions, which means that producers do not reach the standards required by the industry (Adamuchio, Deschamps, \& Machado, 2017).

The different species of the Lamiaceae family show considerable morphological diversity and vary in their trichome densities, which are important taxonomic characteristics that can be used to identify different species. These epidermal appendages have different functions according to their location on the plant, and their formation on different species varies according to the climate characteristics. Most protect the plant against insects, and help regulate humidity and temperature through their direct contact with the external environment (Liu, Liu, \& Zhou, 2012).

Morphological characterization of plant structures and studies on the lavender phytochemical profile have reveal several characteristics that have expanded current knowledge about medicinal plants and their correct identification. These morphological structures have biological properties with specific ecological functions. This variation in morphological characters and volatile constituents may be caused by plant interactions with environmental abiotic factors (Gonçalves \& Romano, 2013; Mambri, 2018). In addition genetic factors are known to influence the yield and chemical composition of the essential oil (Morais, 2009) and may vary within the same species (Properzi, Angelini, Bertuzzi, \& Venanzoni, 2013).

Essential oils, also known as volatile oils, are a multicomponent mixture of natural and volatile compounds formed during secondary metabolism in plants. They are considered to be the main biochemical components in the therapeutic action of medicinal and aromatic plants, and are a raw material of great importance for the food, pharmaceutical, and cosmetic industries (Properzi et al., 2013; Moutassem, Belabid, Bellik, Ziouche, \& Baali, 2019).

It is important to phytochemical and morphological characterization of the each Lavandula species and the various chemotypes within a species if its safety and quality control are to improve. Therefore, the aims of this study were to characterize the morphology of $L$. dentata and determine the content and chemical composition of its essential oil.

\section{Material and Methods}

The species used was L. dentata. The material was confirmed the assistance of plant species specialist. The plant material was collected in spring, 2019 from plants in full bloom grown in Sebollas, Paraíba do Sul district, Rio de Janeiro, which has a tropical climate with a Cwa altitude of $275 \mathrm{~m}$. The research was carried out at the EMBRAPA Agrobiology laboratories (Seropédica-Rio de Janeiro) between September 2019 and January 2020.

Fresh adult plant material consisting of the branches, leaves, and inflorescence were used to verify growth habit, type of branching, classification of the trichomes and epidermis, morphology, and cell arrangement, which was analyzed in triplicate and repeated at least twice.

A measuring tape and a Jomarca digital calliper with a digital clamp and a measurement capacity of $0-150 \mathrm{~mm}$ was used to obtain direct measurements of the aerial parts of the plant and an optical microscope (Zeiss model Axioplan) was used take microscopic measurements. Fine cuts were made with the aid of a scalpel to the stem leaves, bracts, goblets, corolla, and stem. The sections were placed in water that did not contain any dyes, then put between a slide and coverslip, and finally analyzed using optical microscopy and a digital camera in 40 to $400 \times$ increments.

In order to extract the essential oil, one third of the upper part of the branches in full bloom were collected and dried in the shade for $24 \mathrm{~h}$ at room temperature $\left(24\right.$ to $\left.28^{\circ} \mathrm{C}\right)$. Then they were subjected to a hydrodistillation technique in a Clevenger appliance for two hours. The essential oil was extracted using dichloromethane.

The chemical composition of the essential oil from $L$. dentata was determined by chromatographic analysis (HP 5890, Series II and QP2010 Plus-Shimadzu) using GC-FID (gas chromatography coupled with a flame ionization detector) and GC-MS (gas chromatography coupled to mass spectrometry). An HP-5MS capillary column (length: $30 \mathrm{~m}$, internal diameter: $0.25 \mathrm{~mm}$, film thickness: $0.25 \mu \mathrm{m}$ ) with constant flow of $1 \mathrm{~mL} \mathrm{~min}{ }^{-1}$ was used and helium was the carrier gas. The temperature program was from 60 to $260^{\circ} \mathrm{C}$ $\left(3{ }^{\circ} \mathrm{C} \mathrm{min}^{-1}\right.$ ) and the GC-MS ionization had an electron impact of $70 \mathrm{eV}$. The injector temperature was $220^{\circ} \mathrm{C}$ and the temperature of the FID detector was $250{ }^{\circ} \mathrm{C}$. A homologous series of n-alkanes ( $\mathrm{C} 8$ to $\mathrm{C} 20$ ) was used. The molecules were identified by comparing their obtained mass spectrum with those in the library of the NIST electronic database and their linear retention indexes were taken from literature (Adams, 2007).

The essential oil content of $L$. dentata from Paraiba do Sul-Rio de Janeiro was defined as the relationship between the mass of essential oil obtained and the vegetable mass used in the extraction.

\section{Results and Discusion}

The morphometric characteristics of L. dentata specimens analyzed are described in Table 1 . It has a square and very branched stem. The leaves $(30 \times 5.51 \mathrm{~mm})$ of the analyzed material are greyish green and have a hairy, opposite, lanceolate surface, with an acute apex. The edges are curved in the abaxial direction (revolute) throughout the extremity of the limbus and toothed. This is one of the characteristics that distinguishes it from other species (Adamuchio, et al., 2017).

The species has a greyish green color with a quadrangular to star shape and has a layer of trichomes covering the surface, with a simple terminal spike inflorescence (14 x 39 $\mathrm{mm})$ at the end. The plant has pentameric flowers $(4.23 \mathrm{x}$ $8.61 \mathrm{~mm})$, lilac-colored bracts $(6.07 \times 9.96 \mathrm{~mm})$ that may be greenish at the apex (fertile and sterile), and brown or greenish bracts $(8.56 \times 7.8 \mathrm{~mm})$ at the base (fertile) of the inflorescence (Figures 1).

Within the corolla tube, there were characters of systematic importance that defined the species and genera, such as the pistil $(3.8 \mathrm{~mm})$, stamens $(2,1 \mathrm{~mm})$, quadrilocular ovary $(1.3 \mathrm{~mm})$, and spheroidal reticulate pollen grains (0.9 $\mathrm{mm}$ ) (Figure 2), which confirmed on studies in the literature for morphology of certain species of the family Lamiaceae (Doaigey, El-Zaidy, Alfaehan, \& Milagy, 2018). 
Table 1. Morphometric characteristic of the evaluated samples of Lavandula dentata.

\begin{tabular}{lc}
\hline \multicolumn{1}{c}{ Morphometric characteristics } & Size $(\mathrm{mm})$ \\
\hline L. dentata sub-shrub & $60-100$ \\
Leaves & $30 \times 5.51$ \\
Branch diameter & $3-5$ \\
Inflorescence & $14 \times 39$ \\
Upper bracts (sterile or fertile) & $9.89 \times 6.07$ \\
Fertile bracts & $8.56 \times 7.8$ \\
Calyx (sepals) & $5.87 \times 2.42$ \\
petal & $1.93 \times 2.26$ \\
corolla (petals) & 4.23 \\
flower (calyx + corolla) & $8.61 \times 4.23$ \\
peduncle & $12 \mathrm{~cm} \mathrm{x} 1.93$ \\
Ovary & 1.3 \\
Pistil & 3.8 \\
Pollen grain & $0.9 \times 0.52$ \\
\hline
\end{tabular}

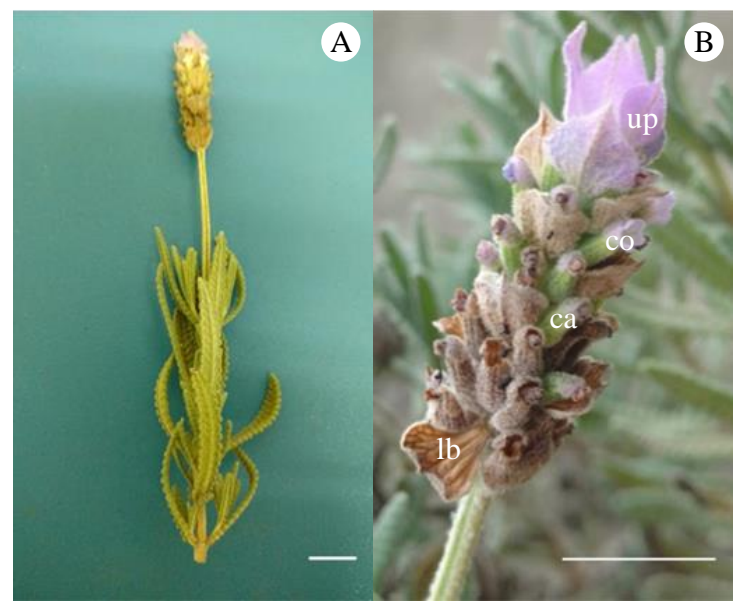

Figure 1: Apical region of a Lavandula dentata branch in bloom: A) Branch with inflorescence, B) Inflorescence: up. upper bracts; lb. lower bract; ca. calyx and co. corolla. Scale bars: $10 \mathrm{~mm}$. Source: authors.

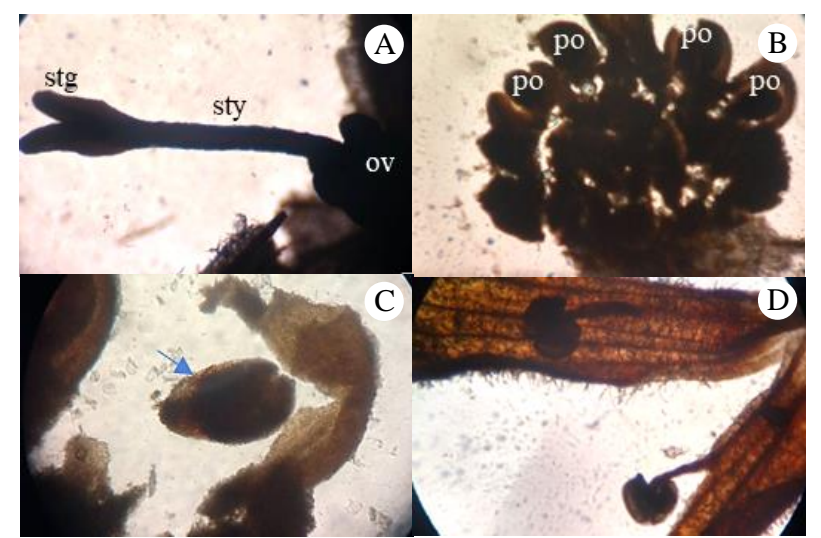

Figure 2: Floral characters of taxonomic importance: A: Carpel: stg. stigma; sty. stylus and ov. Ovary, B: Crushed ovary: po. pollen grain, C: Pollen grain, D: Stamens. Scale bar: $1 \mathrm{~mm}$. Source: authors.

Other morfological features were also verified in the present study, such to the enormous diversity of trichomes covering the aerial part of the plants, the shape and position of the leaves, presence of stomata only on the abaxial face of the leaf blade and an epidermis with juxtaposed cells covered externally by a thick cuticle, which are some of the characteristics common to species adapted to arid climates.

A large number of different non-glandular trichomes that are called tectors and three types of glandular trichomes were found during the morphological evaluation of the aerial part of the plant according to their shape. They differed in size, shape, and number of cells, and were often randomly distributed on the adaxial and abaxial surfaces of the leaves, corollas, goblets, bracts, stems, and branches. According to Biasi \& Deschamps (2009) these epidermal appendages are characteristic of the Lamiaceae family.

Seven types of morphologically distinguishable trichomes were identified on the analyzed samples. There were four types of branched and three types unbranched trichomes identified and are described below:

Ramified tector trichome (RTT): 140-360 $\mu \mathrm{m}$, they were present in large quantities on the surfaces of the leaves (both sides, adaxial and abaxial), peduncles, and inflorescences. They were multicellular, relatively branched, and the cells of the apical extremity were pointed (Figure 3A).

Bifurcated tector trichome (BTT): 41-72 $\mu \mathrm{m}$, this type of trichome was found only in the apical region of the corolla. They were multicellular with a stem composed of a basal cell and a support cell. There were two cells at the apex they had pointed ends (Figure 3B).

Tector trichome with protuberance (TTP): $17.6 \mu \mathrm{m}$, pluricellular and simple with protuberances on the surface of the trichome and a pointed apex. This type was found in large quantities in the corolla (Figure 3C).

Small tector trichome (STT): $11.1 \mu \mathrm{m}$, this type of appendix was very small, sessile, and single-celled. It was only found in the apical region of the petals (Figure 3D).

Our study found a great variety of glands refers to three morphological types of glandular trichomes identified on $L$. dentata with different distribution patterns. In the analyzed plants, glandular trichomes appeared more frequently on the abaxial surface of the leaf blade and their average number was $15 \mathrm{~mm}^{-2}$.

Capitate glandular trichome with bicellular head (CGT): $19.4 \mu \mathrm{m}$, during the mature phase their size was more than double the size of the peltate. There was a spherical head at their extremities that had two secretory cells and a short basal pedicel anterior to the head (Figure 3E).

Glandular trichome capitate with unicellular head (GTCus): $16.21 \mu \mathrm{m}$ there was a small spherical unicellular secretory head at the end of the trichome, with a bicellular supporting stem. This type appeared less frequently in the analyzed samples (Figure 3F).

Peltate glandular trichome (PGTs): 11-21 $\mu \mathrm{m}$, this type during the mature phase had a spherical head that was $21 \mu \mathrm{m}$ in size on average. It had a large secretory cell that was shiny and had a golden appearance (Figures 3G, 3H). 


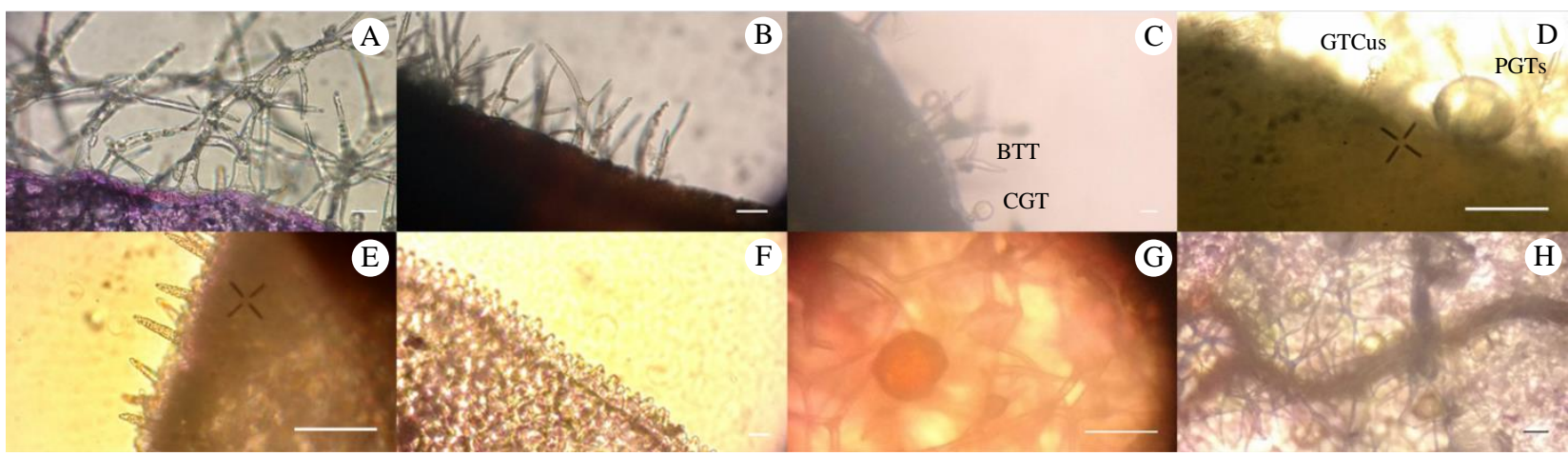

Figure 3: Types of morphologically distinguishable trichomes. Legend: A) Cross section of an apical bract showing a uniseriate epidermis covered by a cuticle and the presence of ramified tector trichomes (RTTs), B) Bifurcated tector trichomes (BTTs), C) Tector trichomes with protuberances (TTPs), D) Small tector trichomes (STT) in petals, with nipple epidermal cells, E) Bifurcated tector trichomes (BTT) and capitate glandular trichomes bicellular head (CGT), which are composed of a two-cell glandular head covered by a smooth cuticle and a body with a short unicellular stem and a unicellular base, F) Glandular trichomes with capitate unicellular heads (GTCus) and peltate glandular trichomes (PGTs), G) Top view of the peltate glandular trichome (PGTs) secreting cell showing a glandular head and smooth cuticle shape, H) Peltate glandular trichome (PGTs) with a shiny, golden appearance. Scale bars: $20 \mu$ m. Source: authors.

The biological properties of lavender have been mainly attributed to the volatile terpenoids, such as monoterpenes and sesquiterpenes (Flores, Blanch, Castilho, \& Herraiz, 2005), and plants of the genus Lavandula are considered to be medicinal and aromatic plants because they produce essential oil secreted secreted who can be used for therapeutic use, by specialized epidermal appendages, the so-called glandular trichomes (Martins, 2002). These trichomes can have single or multicellular pedicels that are uni- or multiseriate and are short or more elongated depending on the species (Biasi \& Deschamps, 2017).

The shape and size of the leaves are very variable. All lavender species have inflorescence, but it varies in morphology and flowering period. Furthermore, its corolla (petals), chalice (sepals) and bracts are characteristic of the species (Benabdelkader et al., 2014).

Justus (2016) identified only a type of non-glandular multicellular branched trichome, differing in this case from the present study, in which the different types of trichomes were separated and yet, the findings were not restricted to pluricellular trichome trichomes. Besides that, the results were not restricted to pluricellular trichomes because glandular trichomes that were capitated and peltated were also found, which was similar to study cited. Furthermore, the results from this study corroborate the reports published in the work about microscopic characters of the leaf and stem of $L$. dentata in order to assist the species identification (Duarte \& Souza, 2014). They identified glandular capitate type trichomes with a uni- or multicellular head that were no branched. Were identified also branched trichomes non-glandular. Likewise, Liu et al. (2012) highlights the presence of glandular and capitate glandular trichomes on $L$. dentata and on other species of the Lamiaceae family.

Haratym and Weryszko-Chmielewska (2017), after analysing Marrabium vulgare (Lamiaceae family) trichomes, found that a branched multicellular non-glandular trichome type was mainly located on the adaxial surface of the leaves and there was an unbranched multicellular type on the abaxial surface of the leaves. Furthermore, they found three types of glandular trichomes that were irregularly distributed: some were present on the adaxial surface of the corolla and a small number were found on the leaves and stems. In this study, no trichomes or appendages were found on the stems; they were only found on the green branches.

The diverse morphology of the epidermal appendages implied that they released different synthesized secretions that had distinct biological functions. In Lamiaceae family members, the peltated glandular trichomes store essential oil, whereas the capitate glandular trichomes contain carbohydrates and alcohols (Biasi \& Deschamps, 2009). In this study, the three types of glandular trichomes were more abundant on the surface of the chalice compared to on the stems, corollas, leaves, and branches. Furthermore Adamuchio et al. (2017) also reported that species belonging to the Lamiaceae family had a large number of these secretory glands in the chalice, which corroborated the results reported in this study.

In the present study the essential oil (OE) content vegetable biomass ratio was 0.75 . In another study, Mambri (2018) data showed out of the parts of the plant used in the extraction, the one third section of the apical aerial part produced the most OE when it was in full bloom (Mambri, 2018). Overall, the OE values suggested that $L$. dentata produced high levels of $\mathrm{OE}$ and the values recorded in this study were much higher than those efficiency of 0.56 and 0.40 for essential oils from leaves and flowers obtained by Martins, Gomes, Malpass and Okura (2019).

A total of 29 chemical compounds were found after analyzing the OE, 26 of which were identified (Table 2). The main constituents were oxygenated monoterpenes $(91.4 \%)$, followed by hydrocarbon monoterpenes (5.12\%), oxygenated sesquiterpenes (1.07\%), and hydrocarbon sesquiterpenes $(0.18 \%)$. This showed that oxygenated monoterpenes represented a high percentage of the $\mathrm{OE}$ components. The major compounds were 1.8 cineole (eucalyptol) (39.43\%), followed by fenchone (18.40\%), fenchol $(5.17 \%)$, and camphor $(20.11 \%)$, in the order of elution of chemical constituents.

These results reaffirmed what was reported by Chhetri, Ali and Setzer (2015). They also reported the presence of 
monoterpenes at high concentrations in the chemical composition of the essential oil from L. dentata.

Table 2. Chemical composition of the essential oil from Lavandula dentata.

\begin{tabular}{|c|c|c|c|c|}
\hline Chemical constituent & $\mathrm{RT}^{1}$ & $\mathrm{RI}^{2}$ & $\mathrm{LRI}^{3}$ & Area\% \\
\hline$\alpha$-pinene & 9.167 & 932 & 926 & 1.46 \\
\hline Camphene & 9.726 & 946 & 941 & 0.85 \\
\hline$\beta$-pinene & 10.83 & 974 & 970 & 2.60 \\
\hline Cineol & 11.35 & 988 & 984 & 0.12 \\
\hline O-cymene & 12.95 & 1022 & 1022 & 0.09 \\
\hline $\begin{array}{l}1,8 \text { cineol } \\
\text { (eucalyptol) }\end{array}$ & 13.40 & 1026 & 1032 & 39.43 \\
\hline$\gamma$-terpinene & 14.34 & 1054 & 1053 & 0.12 \\
\hline Linolool oxide (cis) & 15.01 & 1067 & 1067 & 0.41 \\
\hline Fenchone & 16.00 & 1083 & 1089 & 18.40 \\
\hline Linalool & 16.31 & 1095 & 1096 & 1.50 \\
\hline Fenchol (endo) & 17.10 & 1113 & 1113 & 5.17 \\
\hline$\alpha$-canfolenal & 17.55 & 1122 & 1122 & 0.44 \\
\hline Pinocarveol (trans) & 18.25 & 1135 & 1136 & 0.18 \\
\hline Camphor & 18.74 & 1141 & 1147 & 20.11 \\
\hline Pinocarvana & 19.35 & 1160 & 1159 & 0.83 \\
\hline Borneol & 19.58 & 1165 & 1164 & 1.38 \\
\hline 4-terpineol & 20.04 & 1174 & 1174 & 0.53 \\
\hline$\delta$-terpineol & 20.73 & 1186 & 1188 & 0.56 \\
\hline Mirtenol & 20.96 & 1195 & 1193 & 1.54 \\
\hline Carveol (trans) & 22.02 & 1215 & 1215 & 0.31 \\
\hline Culminal & 23.01 & 1235 & 1236 & 0.42 \\
\hline Carvone & 23.19 & 1239 & 1240 & 0.44 \\
\hline$\beta$-selinene & 34.38 & 1489 & 1481 & 0.18 \\
\hline Karyophylline oxide & 38.54 & 1582 & 1584 & 1.07 \\
\hline$\beta$-endesmol & 41.26 & 1649 & 1652 & 0.76 \\
\hline Bisobolol oxide & 41.59 & 1656 & 1660 & 0.20 \\
\hline
\end{tabular}

${ }^{1}$ Retention time; ${ }^{2}$ calculated retention index; ${ }^{3}$ literature retention index.

Dammak et al. (2019) reported that the main constituent of the essential oil was monoterpene 1,8-cineol (35\%). They found that the $\mathrm{OE}$ had effective antifungal and antiochratoxigenic activities and emphasized the importance of this chemical constituent. This study confirmed the presence of 1,8-cineol as the main component of the $\mathrm{OE}$ and showed that the analysed material used in this study had a high production potential because more OE was extracted than Dammak et al. (2019) achieved in his studies.

Mambri (2018) also obtained results that were similar to this study. The author identified that there was a higher percentage of oxygenated monoterpenes compared to sesquiterpenes in the L. dentata essential OE from Santa Maria, RS, Brazil.

These results obtained by this study made it possible to distinguish $L$. dentata from other species. For example, Lavandula augustifolia, has different $\mathrm{OE}$ values and plant characteristics from $L$. dentata. Furthermore, this study qualitatively analysed the essential oil in L. dentata and reproduced the studies by Dob, Dahmane, Tayeb and
Chelghoumb (2005) who obtained the same chemical constituents and in equivalent proportions.

The study also corroborated Martins et al. (2019). They found similar concentrations of the main constituents in $L$. dentate $\mathrm{OE}$ except that the 1.8 cineol concentration obtained in this study was slightly lower than the concentration achieved by them (40.4 compared to $46.3 \%$ ). The reverse was observed for the constituents camphor (15 compared to $17 \%$ ) and fenchone (13.4 compared to $15.8 \%$ ), which were higher in this study.

The $L$. dentate essential oil from Tunisia had two major components with significantly different percentages: 1.8 cineol (35.0\%) and camphor (32.02\%). Justus (2016) reported a high 1.8 cineol percentage $(63.25 \%)$ in the $L$. dentata essential oil from RS, which was well above the percentage for this chemical constituent produced in this study.

There are many variations in the chemical composition of essential oils. Therefore, analyses of the chemical characteristics of the species that is going to be used should be carried out in order to obtain the most appropriate characteristic for a given application, aiming to improve the effectiveness in its use. According to the literature, genetic, technical, biotic or abiotic factors can directly influence the chemical quality of the $\mathrm{OE}$, and they also determine the variations in major compounds establishing specific biological activity (Morais, 2009).

\section{Conclusion}

Typical characters of $L$. dentata were observed in leaves, stem, inflorescence and trichomes. A large number of nonglandular trichomes were identified, as well as two types of glandular trichomes, including capitate and peltate glandular trichomes. Phytochemical tests determined chemical compounds with a high content of monoterpenes, the main ones being 1.8 cineol (39.43\%), fenchone (18.40\%), fenchol $(5.17 \%)$ and camphor $(20.11 \%)$.

The morphological charactezation and phytochemical allowed to differentiate to correctly $L$. dentata between other closely related lavender species and could provide standard data for the evaluation of plant quality.

\section{References}

Adams, R. P. (2007). Identification of essential oils components by gas chromatography/quadrupole mass spectroscopy (4a ed.). Carol Stream, Illinois: Allured Publishing Corporation.

Adamuchio, L. G. I., Deschamps, C., \& Machado, M. P. (2017). Aspectos gerais sobre a cultura da Lavanda (Lavandula spp.). Revista Brasileira de Plantas Medicinais, 19(4), 483-490. doi: 10.1590/1983-084X/0574.

Benabdelkader, T., Guitton, Y., Pasquier, B., Magnard, J. L., Jullien, F., \& Kameli, A. (2014). Functional characterization of terpene synthases and chemotypic variation in three lavender species of section Stoechas. Physiologia Plantarum, 153(1), 43-57. doi: 10.1111/ppl.12241.

Biasi, L. A., \& Deschamps, C. (2009). Plantas aromáticas: do cultivo à produção de óleo essencial (1a ed.). Curitiba: Layer Studio Gráfico e Editora Ltda.

Chhetri, B. K., Ali, N. A., Setzer, W. N. (2015). A survey of chemical compositions and biological activities of yemeni aromatic medicinal plants. Medicines, 2(2), 67-92. doi: 10.3390\%2Fmedicines2020067.

Dammak, I., Hamdi, Z., Euch, S. K. E. E., Zemni, H., Mliki, A., Hassouna, M., \& Lasram, S. (2019). Evaluation of antifungal and anti- 
ochratoxigenic activities of Salvia officinalis, Lavandula dentata and Laurus nobilis essential oils and a major monoterpene constituent 1,8cineole against Aspergillus carbonarius. Industrial Crops Products, 128, 85-93. doi: 10.1016/j.indcrop.2018.11.006.

Doaigey, A. R., El-Zaidy, M., Alfaehan, A., Milagy, A. E., \& Jacob, T. (2018). Pollen morphology of certain species of the family Lamiaceae in Saudi Arabi. Saudi Journal of Biological Sciences, 25(2), 354-360. doi: 10.1016/j.sjbs.2017.03.001.

Dob, T., Dahmane, D., Tayeb, B., \& Chelghoumb, C. (2005). Chemical composition of the essential oil of Lavandula dentata $\mathrm{L}$. from Algeria. The International Journal of Aromatherapy, 15, 110-114. doi: 10.1016/j.ijat.2005.03.010.

Duarte, M. R., \& Souza, D. C. (2014). Microscopic characters of the leaf and stem of Lavandula dentata L. (Lamiaceae). Microscopy Research and Technique, 77(8), 647-652. doi: 10.1002/jemt.22384.

Flores, G., Blanch, G. P., Castilho, M. L. R., \& Herraiz, M. (2005). Enantiomeric composition studies in Lavandula species using supercritical fluids. Journal of Separation Science, 28(17), 2333-2338. doi: $10.1002 /$ jssc. 200500124 .

Gonçalves, S., \& Romano, A. (2013). In vitro culture of lavenders (Lavandula spp.) and the production of secondary metabolites. Biotechnology Advances, 31(2), 166-174. doi: 10.1016/j.biotechadv.2012.09.006.

Haratym, W., \& Weryszko-Chmielewska, E. (2017). Ultrastructural and histochemical analysis of glandular trichomes of Marrubium vulgare $\mathrm{L}$. (Lamiaceae). Flora, 231, 11-20. doi: 10.1016/j.flora.2017.04.001.

Justus, B. (2016). Morfoanatomia foliar e caulinar, análise química e atividades biológicas do óleo volátil de Lavandula dentata L., Lamiaceae (Masters dissertation). Universidade Estadual de Ponta Grossa, Paraná. Recovered from http://tede2.uepg.br/jspui/handle/prefix/99.

Liu, M., Liu, Z., \& Zhou, J. (2012). Morphology and histochemistry of the glandular trichomes of Isodon rubescens (Hemsley) H. Hara [Lamiaceae]: A promising medicinal plant of China. Journal of Medicinal Plants Research, 6(8), 1455-1460. doi: 10.5897/JMPR11.409.

Mambri, A. P. S. (2018). Yield and composition of lavender essential oil grown in substrate. Horticultura Brasileira, 36(2), 259-264. doi: 10.1590/s0102053620180219.

Martins, M. B. G. (2002). Estudos de microscopia óptica e de microscopia eletrônica de varredura em folhas de Mentha spicata e de Mentha spicata $\mathrm{x}$ suaveolens (Lamiaceae). Bragantia, 61(3), 205-218. doi: 10.1590/S0006-87052002000300002.

Martins, R. P., Gomes, R. A. S., Malpass, A. C. G., \& Okura, M. H. (2019). Chemical characterization of Lavandula dentata $\mathrm{L}$. essential oils grown in Uberaba-MG. Cienc. Rural. Santa Maria, 49(8), 1-7. doi: 10.1590/0103$8478 \mathrm{cr} 20180964$.

Morais, L. A. S. (2009). Influência dos fatores abióticos na composição química dos óleos essenciais. Horticultura Brasileira, 27(2), S4050S4063. Recovered from http://ainfo.cnptia.embrapa.br/digital/bitstream/item/143457/1/2009AA051.pdf.

Moutassem, D., Belabid, L, Bellik, Y., Ziouche, S., \& Baali, F. (2019). Efficacy of essential oils of various aromatic plants in the biocontrol of Fusarium wilt and inducing systemic resistance in chickpea seedlings. Plant Protection Science, 55(3), 202-217. doi: 10.17221/134/2018-PPS.

Properzi A, Angelini P, Bertuzzi G, \& Venanzoni R. (2013). Some biological activities of essential oils. Medicinal \& Aromatic Plants, 2(5), 136. doi: 10.4172/2167-0412.1000136.

License: Creative Commons CC BY 4.0

This article was published with open access for distribution under the terms of the Creative Commons Attribution License, which allows unrestricted use, distribution, and reproduction in any medium, provided the original work is properly cited. 